\title{
Journal of Management, Marketing and Logistics

\section{SUPPLY CHAIN PERFORMANCE: MEASURING THE IMPACT OF SUPPLY CHAIN ORIENTATION AND BRAND EQUITY}

\author{
DOI: 10.17261/Pressacademia.2018.803 \\ JMML- V.5-ISS.1-2018(1)-p.1-17 \\ Ebru Surucu ${ }^{1}$, Gul Denktas Sakar ${ }^{2}$ \\ ${ }^{1}$ Manisa Celal Bayar University, Manisa, Turkey. \\ ebru.surucu@cbu.edu.tr, ORCID: 0000-0002-1224-944X \\ ${ }^{2}$ Dokuz Eylul University, Izmir, Turkey. \\ gul.denktas@deu.edu.tr ORCID: 0000-0002-1072-6150
}

To cite this document

Surucu, E., Sakar, G. D. (2018). Supply chain performance: measuring the impact of supply chain orientation and brand equity. Journal of Management, Marketing and Logistics (JMML), V.5(1), p.1-17.

Permemant link to this document: http://doi.org/10.17261/Pressacademia.2018.803

Copyright: Published by PressAcademia and limited licenced re-use rights only.

\section{ABSTRACT}

Purpose- Aim of this study is twofold. First, there is a gap about how brand related factors affects supply chain performance, this study aims to fulfill this gap by extending existing brand theory with a new setting. Second, this study also aims to reveal the perspectives of manufacturing companies regarding their most important suppliers in terms of supply orientation, suppliers' brand equity and supply chain performance.

Methodology- For this purpose, an online questionnaire is prepared and sent to supply chain managers of manufacturing companies in Aegean region.

Findings- Study results showed that (1) when a supplier has corporate norms and credibility and commitment values, it positively affects supplier's brand image and brand trust; (2) suppliers' brand trust has a positive impact on suppliers' brand equity; (3) suppliers' brand equity impacts whole supply chain's cost \& service-based performance; (4) both suppliers' brand image and brand trust impact whole supply chain's both cost- \& service-based and time- \& operation-based performance.

Conclusion- This research examines how suppliers' supply chain orientation and brand equity affects overall supply chain performance in the context of manufacturing companies; while, contributing our understanding of brand in B2B service settings. For this purpose, a scale has been developed considering supply chain orientation, brand equity, and supply chain performance.

Keywords: Brand equity, brand image, brand trust, supply chain orientation, supply chain performance JEL Codes: L10, L60, M31

\section{INTRODUCTION}

In the globally networked business environment, effective supply chain management is essential to the survival and success of the enterprise; but acquiring and maintaining the performance is becoming increasingly difficult (Davis, 2003). Brands are important market-based (intangible) assets that help firms to create external relationships in the marketplace (Glynn, 2015). The brand is "name, term, sign, symbol, or design, or a combination of them, which is intended to identify the goods and services of one seller or a group of sellers and to differentiate them from those competitors" (Kotler, 1997). Marketing scholars have offered that firms, which can successfully manage their brand, can only achieve a satisfying level of supply chain performance. This new level of supply chain competition brings completely new challenges. Today's business-tobusiness markets, brands, and their power is critically important and linked to the concept of firm performance (Kim and Cavusgil, 2009; Sheth and Parvatiyar, 2000). Brand equity is an important consideration for service marketers (Davis, 2000; Keller, 1993; Keller and Lehmann, 2003) and should be managed like an asset (Aaker, 2003; Davis, 2000; Kim and Cavusgil, 2009). For the modern business environment, intangible firm assets like brand and brand related factors, which is sustainable added value to brand name, has been a major focus area since the early 1990s (Kim and Cavusgil, 2009; Zaichkowsky et al., 2010). These factors are brand equity, brand awareness, brand image and brand trust (Kimpakorn and Tocquer, 2010). 
Although there is considerable research on consumer brands an increasing body of literature on industrial and service brands, there are few studies of how a supplier's brand affects overall supply chain performance. Thus, as an exploratory study, this study examines the relationships between specific characteristics of a supplier's brand equity factor within supply chain orientation and supply chain performance of manufacturing companies. This study is unique since it investigates the relationship between a supply chain orientation, supplier's brand equity, and supply chain performance. The study offers the brand literature with empirical evidence that the supply chain orientation improves supplier's brand equity. In this manner, brand equity is considered to include three dimensions as; brand awareness, brand image, and brand trust. For the supply chain performance literature, this study relates a firm's supply chain performance to a key marketing tool, the supplier's brand. The next section describes the constructs contained in the model and outlines the overall conceptual model. Then research methodology is described which is followed by the study findings. Following the discussion, limitations and suggestions for the future research are provided.

\section{LITERATURE REVIEW}

\subsection{Supply Chain Orientation}

Supply chain orientation (SCO) is defined as "the recognition by a company of the systemic, strategic implications of the activities and processes involved in managing the various flows in a supply chain" (Mentzer, 2001). SCO affects directly firm performance, whilst developing and building sustained relationships with supply chain partners (Mentzer et al., 2001). So, if a firm wants to maintain a positive relationship with their supply chain partners, it should have supply chain orientation. Firm's characteristics of trust, commitment, the sharing of common relationship-building foundations, compatibility between organizations and the support of executive-level management, help to develop firm's SCO (Tinney, 2012). SCO enables creating value for the firm while maintaining the desired level of customer service (Min et al., 2007). SCO elements, which are credibility, benevolence, commitment, corporative norms, organizational compatibility, and top management support, are the main behavior elements that help firms to create supply chain management philosophy (Mentzer et al., 2001). Credibility is defined as "the belief that a trading partner is an expert and reliable in conducting transactions effectively" (Siguaw et al., 1998). Within the supply chain members, a firm must be trusted and credible. Firms that want to trust their supply chain partners must demonstrate an expertise in their field and be a reliable source of knowledge to their upstream and downstream partners (Ganesan, 1994). Benevolence is described as a firm's belief that its partner is interested in the firm's welfare, is willing to accept short-term dislocations, and will not take unexpected actions that would have a negative impact on the firm (Anderson and Narus, 1990; Kumar et al., 1995; Tucker, 2011). When trust achieved between two firms, it will lead to positive working relationships that also leads to generate profitable results for both firms. Commitment, which is the third behavioral element, is "a multi-dimensional construct reflected by the belief in and acceptance of the organization's goal and values, a willingness to exert effort on behalf of the organization, and a strong desire to maintain membership in an organization" (Porter et al., 1974). This relationship creates such a satisfaction that firm does not receive additional benefits by switching supply chain partners (Dwyer et al., 1987). Corporative norms are defined as "the perception of the joint efforts of both the supplier and distributor to achieve mutual and individual goals successfully while refraining from opportunistic actions" (Cannon and Perreault, 1999; Siguaw et al., 1998; Tucker, 2011). Cooperative norms help to establish working procedures for how firms will manage problems and share rewards (Tinney, 2012). Organizational compatibility is defined as "complementary goals and objectives, as well as the similarity in operating philosophies and corporate cultures" (Bucklin and Sengupta, 1993). Firms that want to be compatible organizationally, must operate with similar operating principles, employ a similar cultural environment, and utilize comparable management techniques (Tinney, 2012). Top management support, which includes leadership and commitment to change, is an important antecedent to supply chain management, and the absence of it is a barrier to supply chain management (Jaworski and Kohli, 1993; Lambert et al., 1998; Loforte, 1993; Tucker, 2011). Without the support of executive-level managers, it is possible that the buy-in needed by a firm's employees to support changes in procedures or processes may not occur (Tinney, 2012). In the light of the critical importance of suppliers' brand factors for suppliers' supply chain orientation, the following hypotheses and sub-hypotheses are generated in the study.

Hypothesis 1: Suppliers' supply chain orientation affects suppliers' brand factors positively.

Hypothesis 1.1: Suppliers' supply chain orientation affects suppliers' brand awareness positively.

Hypothesis 1.2: Suppliers' supply chain orientation affects suppliers' brand image positively.

Hypothesis 1.3: Suppliers' supply chain orientation affects suppliers' brand trust positively

Hypothesis 1.4: Suppliers' supply chain orientation affects suppliers' brand equity positively. 


\subsection{Brand Awareness}

One of the components of brand equity is brand awareness (BA), which is defined by Aaker (1991) "the ability of a potential buyer to recognize or recall that a brand is a member of a certain product category". Keller (1993) defined brand awareness as "the customers' ability to recognize the brand as reflected by their ability to identify the brand under different conditions and to link the brand name, logo, symbol and so forth to certain associations in memory". The most fundamental element of brand awareness is the brand name (Davis et al., 2008) and most of the time B2B firms only focus on their brand name familiarity without developing a more comprehensive brand identity (Homburg et al., 2010). This is why, for many B2B firms creating brand awareness -ability to recognize or recall a brand- is the key branding strategy (Celi and Eagle, 2008; Munoz and Kumar, 2004). Building brand awareness allows the formation of brand associations, which consist of attributes and benefits of a brand, which are relevant to the industrial buyer (Glynn, 2015). In B2B context, knowledge about the brand can be enhanced by brand awareness (Keller, 2008). Since brand awareness can be used as a heuristic purchasing decision (Hoyer and Brown, 1990; MacDonald and Sharp, 2000), it can increase supply chain performance which brand is included. Brand awareness acts as a strong signal of product quality and supplier commitment (Hoyer and Brown, 1990; Laroche et al., 1996; MacDonald and Sharp, 2000) because high levels of supplier investment (exhibitions, advertising or packaging) are usually necessary to build high brand awareness (Homburg et al., 2010). Thus, high-quality firms can only meet the high amount of investments for having brand awareness (Erdem et al., 2006; Milgrom and Roberts, 1986). Moreover, brand awareness can be the reflection of presence and substance since high levels of awareness means that firm has been in business for a long time and firm's products have been widely distributed (Aaker, 1991; Hoyer and Brown, 1990).

Since brand awareness is one of the components of brand equity, it is expected that changes in brand awareness affect brand equity (Pouromid and Iranzadeh, 2012). Moreover, supplier's brand with higher levels of awareness within the supply chain is expected to affect supply chain performance overall compared with unknown supplier's brand. Researchers argue that relationship between supplier's brand awareness and supplier's brand equity in consumer context will be in the same vein as it is in B2B service context (Aaker, 1991; Davis et al., 2008; Gordon et al., 1993). Moreover, it is argued in this study that supplier's brand awareness affects overall supply chain performance as well. Based on the relevant literature, the hypotheses for brand awareness are proposed as below:

Hypothesis 2.1: Suppliers' brand awareness affects suppliers' brand equity positively.

Hypothesis 2.2: Suppliers' brand awareness affects supply chain performance positively.

\subsection{Brand Image}

Marketing researchers suggested that brand image is a vital element of brand equity (Keller, 1993). Brand image (BI) is defined as a subjective and perceptual phenomenon formed through consumer interpretation; including certain characteristics of the product or service's symbolic meanings (Dobni and Zinkham, 1990; Padgett and Allen, 1997). The brand image describes the consumer's thoughts and feelings towards the brand (Roy and Banerjee, 2007). Brand image can be seen as the overall mental image that consumers have a brand, and its uniqueness in comparison to the other brands (Faircloth, 2005). Moreover, brand image plays an important role in B2B markets where tangible quality features are harder to distinguish (Mudambi et al., 1997). In B2B market relations, such as supply chain relationships, the brand image becomes really important because every interaction between a company and its stakeholders becomes an input for the brand image (Davis et al., 2009). Aaker (1996) stated that, firm attributes like experience and reputation are centered in B2B brand image are generally a company's most valuable but underused assets (Aaker, 1996). Some of the researchers mention that brand image is an important industrial marketing tool (Lorge, 1998; Shaw et al., 1989; Sinclair and Seward, 1988; Mudambi, 2002). However, there is little evidence about that B2B customers are influenced by emotional associations they make with their supplier (Roper et al., 2002).

It is hard to imitate and it becomes costly to compete with other firms when a firm has positive and strong brand image in customers' mind (Carpenter and Nakamoto, 1989). Focal firms with strong brand images can also have this favorable position. Moreover, supplier's brand with higher levels of the image within the supply chain is expected to affect supply chain performance overall compared with unknown supplier's brand. It is argued that supplier's brand image affects overall supply chain performance. The hypotheses for the brand image are proposed as below:

Hypothesis 3.1: Suppliers' brand image affects suppliers' brand equity positively.

Hypothesis 3.2: Suppliers' brand image affects supply chain performance positively.

\subsection{Brand Trust}

Brand trust (BT) is a component of brand equity (Kimpakorn and Tocquer, 2010) and "perhaps the single most powerful relationship marketing tool available to a company" (Berry, 1995). BT consists of past experience and previous interactions (Ravald and Grönross, 1996; Rempel et al., 1985). BT is defined as "the willingness of the average consumer to rely on the 
ability of the brand to perform its stated function" (Chaudhuri and Holbrook, 2001), and comprised of after consumers' evaluation of firms' offerings. If firms are able to give belief of safety, honesty, and reliability about their brands to consumers, brand trust can be achieved (Doney and Cannon, 1997). Brand trust has two dimensions; viability and intentionality (Delgado-Ballester, 2011). The first dimension is related to the satisfying consumers' needs and demands; while creating an idea in consumers' mind that brand accomplishes its value promising (Deighton, 1992). Moreover, this dimension focuses on satisfying consumers' needs in consistently positive ways. The second dimension, intentionality is covered with the belief that the brand will not take advantage of the consumer's vulnerability (Delgado- Ballester, 2011). Trust is an important variable in building strong supply chain networks (Sahay, 2003) and it is related to brand equity (Kimpakorn and Tocquer, 2010). In the supply chain, partners develop trust in a brand based on positive beliefs considering their expectations and future performances of the firm (Ashley and Leonard, 2009). The domain of trust in this study is how it affects suppliers' brand equity and how suppliers' brand trust affects supply chain performance overall. Since brand trust one of the components of brand equity, it is expected that changes in brand trust affect brand equity. Moreover, supplier's brand with higher levels of trust within the supply chain is expected to affect supply chain performance overall compared with unknown supplier's brand. Moreover, we argue that supplier's brand image affects overall supply chain performance as well. Based on the literature, the hypotheses for this research is proposed as below:

Hypothesis 4.1: Suppliers' brand trust affects suppliers' brand equity positively.

Hypothesis 4.2: Suppliers' brand trust affects firms' supply chain performance positively.

\subsection{Brand Equity}

Brand equity $(\mathrm{BE})$ has been viewed from a variety of perspectives, which are marketing and finance (Motameni and Shahrokhi, 1998). Brand equity is the "added value" with which a brand endows a product, whilst imparts the competitive advantage to the firm (Farquhar, 1989). For the financial perspective, brand equity is defined as "the incremental cash flow that accrues to branded products over unbranded products" (Simon and Sullivan, 1993). Most widely cited brand equity conceptualizations are those of Aaker (1991) and Keller (1993). Aaker (1991) defined brand equity as "a set of brand assets and liabilities linked to a brand, its name, and symbol that add to or subtract from the value provided by a product or service to a firm and/or to that firm's customers". According to Aaker (1996), brand awareness, brand association, brand loyalty, and perceived quality are the sources of brand equity knowledge structure. Keller (1993) defined as "the differential effect of brand knowledge on consumer response to the marketing of a brand" and developed the behavioral concept of consumer-based brand equity (CBBE), which consists of the two dimensions of brand awareness and brand image and is defined as the differential effect of brand knowledge on customer response to the marketing of the brand. According to Keller (1993), brand equity consists of brand awareness, brand image, and brand loyalty. Both scholars offered that the strength of a brand can be measured by examining consumers' associations with a brand and their positive responses to the brand (Celi and Eagle, 2008). In the literature, measurement of consumer-based brand equity has been studied with five dimensions - brand awareness, perceived quality, brand association, brand image and brand loyalty (Cho, 2011). Those five dimensions have been used partially or wholly in studies (Buil et al., 2008; Carroll and Ahuvia, 2006; Keller, 1993; Keller, 2001; Kim et al., 2003; Kim et al., 2009; Kimpakorn and Tocquer, 2010; Low and Lam, 2000; Yoo et al., 2000; Yoo and Donthu, 2001; Yoo and Donthu, 2002). In this study, brand awareness, brand image, and brand trust are used as dimensions of brand equity. In B2B marketing, brand equity is a critical competitive driver, as it is in consumer marketing (Kotler and Proertsch, 2007; Mudambi, 2002; Webster et al., 2004). When a brand's strength increases, B2B market buyers become more likely to repurchase and pay a price premium (Bendixen et al., 2004; Hutton, 1997; Kim and Hyun, 2011; Roberts and Merrilees, 2007; Taylor et al., 2007). Supplier's brand with higher levels of equity within the supply chain is expected to affect supply chain performance overall compared with unknown supplier's brand. Thus, it is argued that supplier's brand equity affects overall supply chain performance of the company. The hypotheses are proposed as below:

Hypothesis 5: Suppliers' brand equity affects supply chain performance positively.

\subsection{Supply Chain Orientation}

While measuring performance in the supply chain, the measurement system may reflect a system of measuring the immeasurable. In supply chain performance measurement, control is no longer based on ownership only, but rather on networking across interfaces. Activities that are not under the control of an individual company (manufacturer) have to be measured and controlled (by the manufacturer and its supply chain partners), making the supply chain transparent, to a level not experienced before and leading the way for performance improvements (Gawankar et al., 2016; Hoek, 1998). Researchers and practitioners have developed and improved measures that can be used to establish supply chain performance, since the importance of management of supply chain has been increased. The measurement of supply chain performance requires the creation of inter- and intra-organization assessment system. These systems can be used to identify opportunities for improved supply chain efficiency and competitiveness, to help understand how companies operating in supply chains affect each other's performance, to support the supply chain in satisfying consumer 
requirements and to assess the results of an implemented initiative (Lyons et al., 2012). In the literature, there are many different types of measurement for supply chain performance (Gunesakaran et al., 2001; Lee and Billington, 1992). A framework can include three major categories of metrics: service measures, cost measures and return on assets measures. Considering service, firms can use systems to measure specific elements like order cycle time, order fill rates, damage rates, error rates in picking orders, achievement of the "perfect order" and so on (Brewer and Speh, 2000; Stewart, 1995). For cost measures, firms can use cost per order, logistics cost per unit and cost per unit for each functional area of logistics (storage cost per unit, per square foot). For return on asset measure, firms generally determine the extent to which their investment in logistics assets is earning the desired financial returns (Brewer and Speh, 2000).

Supply chain performance measurement can be done in strategic, tactical, and operational levels (Gunesakaran, 2004). Also, different types of supply chain performances are used in literature (Christopher, 1992; Cohen and Lee, 1990; Davis, 2003; Lambert and Sharman, 1990; Lee and Billington, 1992; Loforte, 1993). As a performance measures; average finished goods inventory, demand fulfillment (Levy, 1995); order cycle time, order completeness (Christopher, 1992); delivery performance, lead time, level of defects and responsiveness (Lambert and Sharman, 1990); material inventory, work in process inventory, fill rates, stock out frequencies and lead time (Cohen and Lee, 1990); inventory levels, inventory investment, order fill rate, line item fill rate and the average number of days late (Davis, 2003); inventory turns, line item fill rate, order item fill rate, total order cycle time, total response time to an order, average backorder levels and average variability in delivery (Lee and Billington, 1992) are employed by the researchers. However, it is clear that researchers haven't reached a consensus about a stable set of measures that are used for measuring the performance of the supply chain for all types of studies (Bhatnagar and Sohal, 2005).

\section{DATA AND METHODOLOGY}

A survey method is employed to test measures of supply chain orientation, brand factors- brand awareness, brand image, brand trust and brand equity-, in the context of supply chain performance. Measurement items were drawn from existing scales as reported in the following section.

\subsection{Scale Development}

Measurement items for each construct are borrowed from the relevant literature. Moreover, interviews have been made with logistics industry experts to identify the appropriate language for adopting measurement items to the supply chain management context. The questionnaire included five parts. First two parts included basic demographic information about firm and respondents. Third, fourth and fifth parts were used to gather information about assessing market orientation, brand related factors, and supply chain performance, respectively. All items except demographic information were measured on a 5-point Likert-type scale from "strongly disagree" (1) to "strongly agree" (5). The informants were asked to answer questions according to their perception of brand-related factors. Third part measures SCO with the help of credibility, commitment, and corporative norms elements. The items for credibility and commitment were adopted from (Siguaw et al., 1998), and cooperative norms from (Cannon and Perreault, 1999). Fourth part measures brand equity factors. Items for brand awareness are adopted from (Davis et al., 2009; Yoo and Donthu, 2001) while the items for the brand image are adopted from (Davis et al., 2009). Measurement items for brand trust are adopted from (Han and Sung, 2008). Lastly, items for brand equity are adopted from (Davis et al., 2009; Kim and Cavusgil, 2009). The last part of the questionnaire measures supply chain performance. For supply chain performance, lead-time, inventory management, time to market, quality, customer service and flexibility (Bhatnagar and Sohal, 2005) and order fill rates, error rates in picking orders (Brewer and Speh, 2000; Stewart, 1995) variables were employed. Also, during the interviews, opinions of logistics industry and supply chain experts about the supply chain performance measurement items were taken, and according to their suggestions, five more variable was added to supply chain performance measurement scale as cost, delivery on time, delivery on the right place, delivery on the right amount of product and high accuracy of order estimation. In accordance with the relevant literature and the items employed in the questionnaire, a conceptual model visualized in Figure 1 is suggested. 


\section{Figure 1: Conceptual Model}

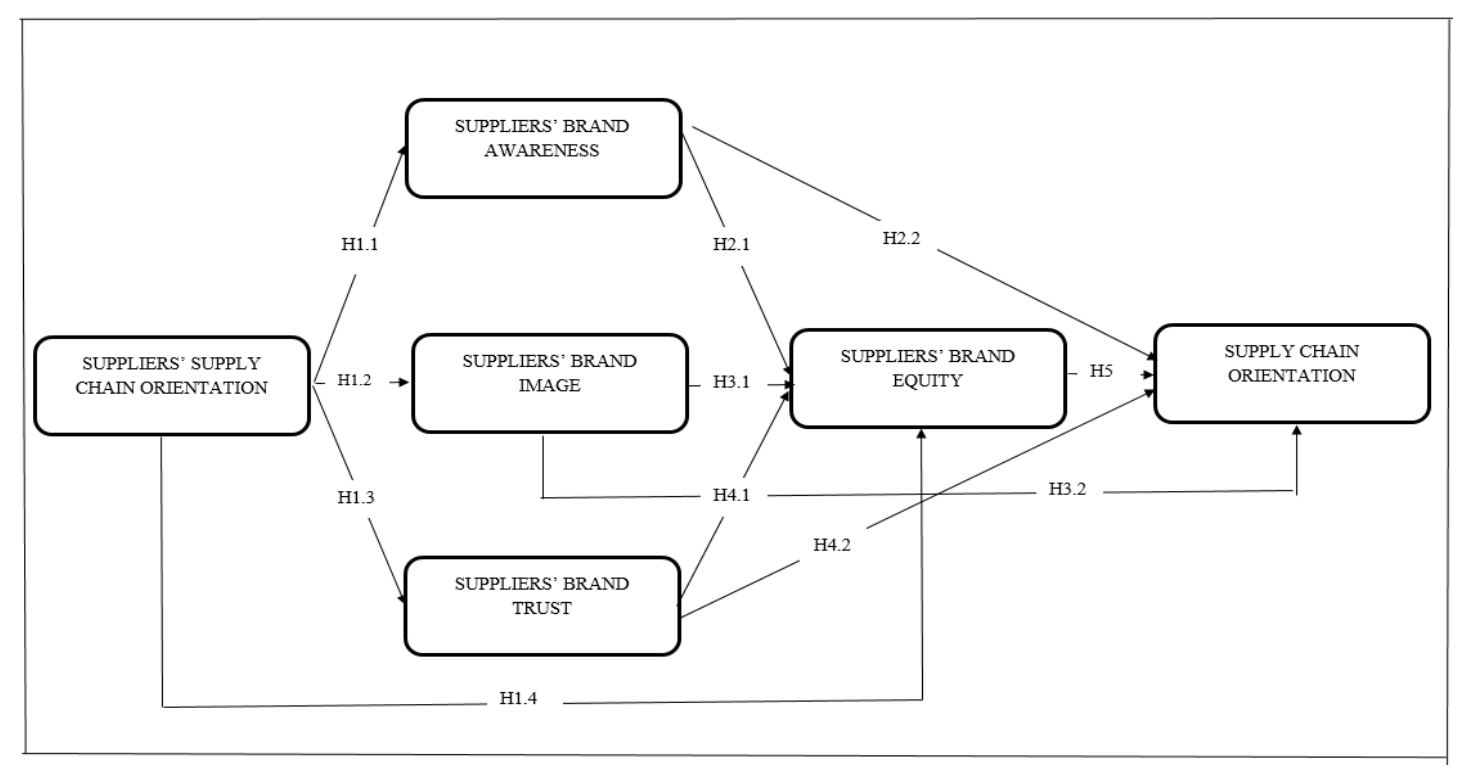

\subsection{Sample and Data Collection}

This study examines supply chain performance at the business unit level. The most appropriate informant for this study was considered as the supply chain manager, and in cases where firms did not have a supply chain manager, procurement/purchasing manager, marketing manager, and general/vice managers were added as potential participants. Four-week deadline has been set and within this duration, 35 managers responded to the survey. The online survey was sent to the mailing list of Aegean Exporters' Association, ESBAS Aegean Free Zone, and Manisa Organized Industrial Zone. Although reminding e-mails were sent to these mailing lists, only a total of 35 usable questionnaires were collected. All analyses have made with SPSS 21.0. Table 1 shows the characteristics of the participant firms.

\section{Table 1: Characteristics of Sample}

\begin{tabular}{|l|c|}
\hline Company Characteristics & Number of Respondents (percent) \\
\hline Industry: & \\
Mining & $2(5.7)$ \\
Textile & $3(8.6)$ \\
Chemistry, petrol, plastic & $3(8.6)$ \\
Energy & $3(8.6)$ \\
Metal & $3(8.6)$ \\
Machine \& equipment & $1(2.9)$ \\
Automotive & $11(31.4)$ \\
Food & $4(11.4)$ \\
Others & $3(8.6)$ \\
Total & $35(100)$ \\
\hline S100 million TL & \\
$100,000,001$ TL -500 million TL & $15(42,9)$ \\
$500,000,001$ TL -1 billion TL & $8(22,9)$ \\
$1,000,000,001$ TL -5 billion TL & $1(2,9)$ \\
Not Reported & $4(11,4)$ \\
Total: & $7(20)$ \\
Annual Sales: & $35(100)$ \\
500 & \\
$501-1,000$ & $27(77.1)$ \\
$1,001-5,000$ & $3(8.6)$ \\
$>10,001$ & $4(11.4)$ \\
Total & $1(2.9)$ \\
& $35(100)$ \\
\hline Number Employees: &
\end{tabular}




\section{FINDINGS AND DISCUSSIONS}

\subsection{Reliability and Validity}

Cronbach's Alpha value was 0.822 for SCO variables, 0.893 for suppliers' brand factors and 0.944 for SCP factors. Since Cronbach's Alpha values are greater than 0.7 , all items were considered reliable in the study.

Table 2: Reliability Statistics

\begin{tabular}{|l|c|c|}
\hline & Cronbach's Alpha & N of Items \\
\hline Supply Chain Orientation & .822 & 5 \\
Suppliers' Brand Factors & .893 & 18 \\
Supply Chain Performance & .944 & 13 \\
\hline
\end{tabular}

\subsection{Factor Analysis Results}

SPSS 21.0 software is used to analyze the data. Data is examined in the SPSS output for Kaiser-Meyer-Olkin (KMO) on 35 samples for SCO, suppliers' brand factors and SCP. As a result, which is shown in Table 3, the KMO measure indicated a very high sampling adequacy and good preconditions for factor analyses. In addition, results of Bartlett's Test for Sphericity had significant differences. According to the below test results, the samples were suitable for factor analyses.

Table 3: KMO and Bartlett's Test of SCO, Suppliers' Brand Factors \& SCP

\begin{tabular}{|l|c|c|c|}
\hline & SCO & Suppliers' Brand Factors & SCP \\
\hline Kaiser-Meyer-Olkin Measure of Sampling Adequacy & & & \\
\hline Bartlett's Test of Sphericity & .788 & .650 & .847 \\
Approx. Chi-Square & & & 342,829 \\
Df & 59,304 & 416,067 & 78 \\
Sig. & 10 & 153 &, 000 \\
\hline
\end{tabular}

An exploratory factor analysis PCA (Principal Component Analysis) and varimax rotation were conducted. Factors are listed in Table 4.

Table 4: Factors for SCO

\begin{tabular}{|c|c|c|c|c|c|c|}
\hline \multicolumn{2}{|c|}{ Factors } & Alpha & Mean * & Std. & I** & II \\
\hline \multicolumn{2}{|c|}{ Factor 1: Corporate Norms-Related Orientation } & .763 & & & & \\
\hline $\mathrm{SCO} 4$ & $\begin{array}{l}\text { Our most important supplier is willing to make cooperative } \\
\text { changes in our supply chain. }\end{array}$ & & 3.80 & .759 & .910 & \\
\hline SCO5 & $\begin{array}{l}\text { Our most important supplier views its business as a value-added } \\
\text { piece of work to the whole supply chain. }\end{array}$ & & 3.86 & .974 & .793 & \\
\hline \multicolumn{2}{|c|}{ Factor 2: Credibility \& Commitment Related Orientation } & .757 & & & & \\
\hline $\mathrm{SCO} 2$ & $\begin{array}{l}\text { Our most important supplier is knowledgeable regarding our } \\
\text { products and/or services when they are doing business with our } \\
\text { supply chain members. }\end{array}$ & & 4.11 & .583 & & .830 \\
\hline SCO1 & $\begin{array}{l}\text { Promises made to our supply chain members by our most } \\
\text { important supplier is reliable. }\end{array}$ & & 3.94 & .802 & & .777 \\
\hline SCO3 & $\begin{array}{l}\text { Our most important supplier is patient with supply chain } \\
\text { members when they make mistakes that cause trouble to } \\
\text { suppliers but are not repeated. }\end{array}$ & & 3.71 & .860 & & .768 \\
\hline
\end{tabular}

\footnotetext{
*Five-point scale 1: poor 5: excellent

**The Roman numerals refer to the number of factors
}

Factor 1 measures whether the suppliers try to achieve mutual and individual goals while avoiding opportunistic actions and the factor is named as "corporate-norms related orientation". According to factor analysis results, this factor contains two variables. The highest factor loading is 0.910 , which measures corporative norms. SCO5 is the second variable that has the 0.793 -factor loading and it measures corporative norms. Cronbach's Alpha value is 0.763 for the Factor 1 . Factor 2 measures whether the supply chain partner is a reliable and sees the supply chain as an organization and behaves on behalf of organization's favor. The factor is named as "credibility and commitment-related orientation". According to factor analysis results, this factor contains three variables. SCO2 has the highest factor loading is with 0.830 point, which measures credibility. SCO1 is the second variable that has the 0.777 -factor loading measures credibility and lastly, SCO3, which 
measures commitment, has 0.768 -factor loading. Moreover, Cronbach's Alpha value is 0.757 for the Factor 2 . Factors for suppliers' brand factors are shown in Table 5.

Table 5: Factors for suppliers' brand factors

\begin{tabular}{|c|c|c|c|c|c|c|c|c|c|}
\hline \multicolumn{2}{|c|}{ Factors } & Alpha & $\begin{array}{l}\text { Mean } \\
*\end{array}$ & Std. & $I^{* *}$ & II & III & IV & V \\
\hline \multicolumn{2}{|c|}{ Factor 1: Suppliers' brand image } & .892 & & & & & & & \\
\hline $\mathrm{B} 12$ & $\begin{array}{l}\text { We can reliably predict how the most important } \\
\text { supplier in our supply chain will perform. }\end{array}$ & & 3.77 & .910 & .864 & & & & \\
\hline BI1 & $\begin{array}{l}\text { The most important supplier in our supply chain is } \\
\text { known as a firm that takes good care of its trade } \\
\text { partners. }\end{array}$ & & 3.83 & .822 & .851 & & & & \\
\hline BI5 & $\begin{array}{l}\text { The most important supplier in our supply chain is } \\
\text { a prestigious firm. }\end{array}$ & & 4.11 & .718 & .829 & & & & \\
\hline BT1 & $\begin{array}{l}\text { The most important supplier in our supply chain } \\
\text { meets its obligations to us. }\end{array}$ & & 4.00 & .767 & .801 & & & & \\
\hline $\mathrm{BI} 3$ & $\begin{array}{l}\text { In comparison to other suppliers, the most } \\
\text { important supplier in our supply chain is known to } \\
\text { consistently deliver very high quality. }\end{array}$ & & 3.86 & .845 & .614 & & & & \\
\hline \multicolumn{2}{|r|}{ Factor 2: Suppliers' brand equity } & .823 & & & & & & & \\
\hline BE5 & $\begin{array}{l}\text { We feel a strong emotional connection to our most } \\
\text { important supplier's brand. }\end{array}$ & & 2.71 & 1.017 & & .873 & & & \\
\hline BE1 & $\begin{array}{l}\text { We are willing to pay more in order to do business } \\
\text { with our most important supplier. }\end{array}$ & & 2.80 & .964 & & .648 & & & \\
\hline BE3 & $\begin{array}{l}\text { The most important supplier' brand gives us an } \\
\text { advantage over our competitors. }\end{array}$ & & 3.17 & 1.175 & & .625 & & & \\
\hline BE2 & $\begin{array}{l}\text { The most important supplier's brand is different } \\
\text { from other suppliers. }\end{array}$ & & 3.74 & .741 & & .488 & & & \\
\hline BE4 & $\begin{array}{l}\text { We perceive our most important supplier's brand } \\
\text { as prestigious. }\end{array}$ & & 3.57 & 1.092 & & .482 & & & \\
\hline \multicolumn{2}{|r|}{ Factor 3: Suppliers' brand awareness } & .744 & & & & & & & \\
\hline BA4 & $\begin{array}{l}\text { Compared to other suppliers, our most important } \\
\text { supplier is a leading brand in the industry. }\end{array}$ & & 4.09 & .742 & & & .869 & & \\
\hline BA1 & $\begin{array}{l}\text { The name of our most important supplier is well- } \\
\text { known in our industry. }\end{array}$ & & 4.34 & .873 & & & .772 & & \\
\hline BA2 & $\begin{array}{l}\text { The most important supplier in our supply chain is } \\
\text { the industry leader in brand awareness. }\end{array}$ & & 3.73 & 1.017 & & & .631 & & \\
\hline \multicolumn{2}{|c|}{ Factor 4: Suppliers' brand trust } & .654 & & & & & & & \\
\hline BT2 & $\begin{array}{l}\text { The most important supplier in our supply chain is } \\
\text { trustworthy. }\end{array}$ & & 3.89 & .900 & & & & .732 & \\
\hline BA3 & $\begin{array}{l}\text { Our most important supplier is recognized by other } \\
\text { members of our supply chain as a strong trade } \\
\text { partner. }\end{array}$ & & 3.66 & .906 & & & & .668 & \\
\hline $\mathrm{B} \mid 4$ & $\begin{array}{l}\text { The most important supplier in our supply chain } \\
\text { has a rich brand history. }\end{array}$ & & 3.71 & .710 & & & & .605 & \\
\hline \multicolumn{2}{|c|}{ Factor 5: Suppliers' brand communication } & .847 & & & & & & & \\
\hline BE7 & $\begin{array}{l}\text { We pay attention advertising and the information } \\
\text { that comes from our most important supplier. }\end{array}$ & & 3.37 & .973 & & & & & .954 \\
\hline BE6 & $\begin{array}{l}\text { We remember adverting and information that } \\
\text { comes from our most important supplier. }\end{array}$ & & 3.23 & 1.140 & & & & & .855 \\
\hline
\end{tabular}

*Five-point scale 1: poor 5: excellent

**The Roman numerals refer to the number of factors 
Factor 1 measures whether supplier takes good care of its partners (BI1), produce high-quality products constantly (BI3), fulfill its responsibilities (BT1), is a respected firm (BI5) and manufacturer's trust about its future performance (BI2). Factor 1 named as "suppliers' brand image". Factor 2 measures whether a manufacturer feels an emotional attachment to the supplier (BE5), ready to pay more to continue doing business with that supplier (BE1), gets an edge over competitors by working with that supplier (BE3), feels prestigious by working with that supplier (BE4) and the brand of the supplier is different than competitors' brand (BE2) and the factor is named as "suppliers' brand equity". Factor 3 measures whether the supplier is a leading brand in the industry (BA4), supplier's name is a well-known (BA1) and supplier's brand is a wellrecognized (BA2). For these reasons, the factor is named as" suppliers' brand awareness". Factor 4 measures whether the supplier has a rich brand history (BI4), has a trustworthy brand (BT2) and is a powerful partner (BA3) from the perspective of the manufacturer and it is named as "suppliers' brand trust". Factor 5 measures whether manufacturer gives attention (BE6) and remembers (BE7) the information and advertisements sent by the supplier. Even though these variables were considered as brand equity variables at the beginning stage of the study, factor analysis results showed that they are grouped under different factor and it is named as "suppliers' brand communication".

In the paper, an exploratory factor analysis PCA (Principal Component Analysis) and varimax rotation conducted on responses from 35 individuals for each item. The Kaiser rule is to drop all components with eigenvalues under 1.0. However, according to anti-image matrix results, it is seen that SCP6, SCP9, SCP12 and SCP13 MSA value smaller than 0.5 (Field, 2005). Thus, those variables are expelled from the analysis. Factors for SCP is shown in Table 6.

Table 6: Factors for Supply Chain Performance

\begin{tabular}{|c|c|c|c|c|c|c|}
\hline Factor & & Alpha & Mean * & Std. & $I^{* *}$ & II \\
\hline Factor & Cost and Service-Based Performance & .897 & & & & \\
\hline SCP11 & $\begin{array}{l}\text { Working with the most important supplier in our supply } \\
\text { chain enhances supply chain performance with regard to } \\
\text { flexibility. }\end{array}$ & & 3.83 & .785 & .882 & \\
\hline SCP10 & $\begin{array}{l}\text { Working with the most important supplier in our supply } \\
\text { chain enhances supply chain performance with regard to } \\
\text { customer service. }\end{array}$ & & 3.69 & .932 & .851 & \\
\hline SCP5 & $\begin{array}{l}\text { Working with the most important supplier in our supply } \\
\text { chain enhances supply chain performance with regard to } \\
\text { requested amount delivery. }\end{array}$ & & 3.97 & .857 & .774 & \\
\hline SCP1 & $\begin{array}{l}\text { Working with the most important supplier in our supply } \\
\text { chain enhances supply chain performance with regard to } \\
\text { cost. }\end{array}$ & & 3.89 & .900 & .747 & \\
\hline SCP8 & $\begin{array}{l}\text { Working with the most important supplier in our supply } \\
\text { chain enhances supply chain performance with regard to } \\
\text { time to market. }\end{array}$ & & 3.77 & .910 & .632 & \\
\hline Factor & Time and Operation-Based Performance & .870 & & & & \\
\hline SCP2 & $\begin{array}{l}\text { Working with the most important supplier in our supply } \\
\text { chain enhances supply chain performance with regard to } \\
\text { on-time delivery. }\end{array}$ & & 3.97 & .747 & & .841 \\
\hline SCP4 & $\begin{array}{l}\text { Working with the most important supplier in our supply } \\
\text { chain enhances supply chain performance with regard to } \\
\text { delivery on right place. }\end{array}$ & & 3.80 & .833 & & .807 \\
\hline SCP7 & $\begin{array}{l}\text { Working with the most important supplier in our supply } \\
\text { chain enhances supply chain performance with regard to } \\
\text { smallest error rates in picking order. }\end{array}$ & & 4.00 & .728 & & .786 \\
\hline SCP3 & $\begin{array}{l}\text { Working with the most important supplier in our supply } \\
\text { chain enhances supply chain performance with regard to } \\
\text { lead-time. }\end{array}$ & & 3.89 & .832 & & .771 \\
\hline
\end{tabular}

*Five-point scale 1: poor 5: excellent

**The Roman numerals refer to the number of factors

Factor 1 measures supply chain performance with flexibility (SCP11), customer service (10), requested amount delivery (SCP5), cost (SCP1) and time to market (SCP8) and this factor is named as "cost and service-based performance". Factor 2 measures supply chain performance with on-time delivery (SCP2), delivery on the right place (SCP4), smallest error rates in picking order (SCP7) and lead-time (SCP3). 
Although a preliminary conceptual model is given in the previous section, there was a need for modification in the conceptual model since SCO factor was divided into two as "corporate norms-related and credibility" and "commitmentrelated orientation"; while supplier's brand factors were divided into 5 factors as "supplier's brand image", "supplier's brand equity", "supplier's brand awareness", "supplier's brand trust" and a new factor of "supplier's brand communication" was added. Moreover, in the SCP part, two new factors, which are "cost and service-based performance" and "time and operation-based performance" were added. Thus, modified conceptual model and hypotheses are shown below.

H1. Suppliers' supply chain orientation affects suppliers' brand factors positively.

H.1.1. Suppliers' corporate norms affect brand factors positively.

H1.1.a Suppliers' corporate norms affect brand image positively.

H1.1.b Suppliers' corporate norms affect brand awareness positively.

H1.1.c Suppliers' corporate norms affect brand trust positively.

H1.1.d Suppliers' corporate norms affect brand communication positively.

H1.2. Suppliers' credibility \& commitment affects brand factors positively.

H1.2.a Suppliers' credibility \& commitment affects brand image positively.

H1.2.b Suppliers' credibility \& commitment affects brand awareness positively.

H1.2.c Suppliers' credibility \& commitment affects brand trust positively.

H1.2.d Suppliers' credibility \& commitment affects brand communication positively.

H2. Suppliers' supply chain orientation affects suppliers' brand equity positively.

H2.1 Suppliers' credibility \& commitment affects brand equity positively.

H2.2 Suppliers' corporate norms affect brand equity positively.

H3. Suppliers' brand factors affect suppliers' brand equity positively.

H3.1 Suppliers' brand awareness affects suppliers' brand equity positively.

H3.2 Suppliers' brand image affects suppliers' brand equity positively.

H3.3 Suppliers' brand trust affects suppliers' equity positively.

H3.4 Suppliers' brand communication affects suppliers' brand equity positively.

H4. Suppliers' brand equity affects supply chain performance positively.

H4.1 Suppliers' brand equity affects supply chain's cost \& service-based performance.

H4.2 Suppliers' brand equity affects supply chain's time \& operation-based performance.

H5. Suppliers' brand factors affect supply chain performance positively.

H5.1 Suppliers' brand awareness affects supply chain performance positively.

H5.1.a Suppliers' brand awareness affects supply chain's cost \& service-based performance.

H5.1.b Suppliers' brand awareness affects supply chain's time \& operation-based performance.

H5.2 Suppliers' brand image affects supply chain performance positively.

H5.2.a Suppliers' brand image affects supply chain's cost \& service-based performance.

H5.2.b Suppliers' brand image affects supply chain's time \& operation-based performance.

H5.3 Suppliers' brand trust affects supply chain performance positively.

H5.3.a Suppliers' brand trust affects supply chain's cost \& service-based performance.

H5.3.b Suppliers' brand trust affects supply chain's time \& operation-based performance.

H5.4 Suppliers' brand communication affects supply chain performance positively. 
H5.4.a Suppliers' brand communication affects supply chain's cost \& service-based performance.

H5.4.b Suppliers' brand communication affects supply chain's time \& operation-based performance.

\subsection{Correlation Analysis Results (Hypothesis Testing)}

In the study, parametric tests are implemented to see whether there is a relationship between demographic variables (industry, firm size and ownership structure) and supply chain performance. To see whether there is a difference between industry type and supply chain performance, first Levene test is applied which controls homogeneity. After Levene test is applied, SPSS cannot able to perform tests because of low variable size.

To see whether there is a difference between firm size and supply chain performance, again Levene test is applied and results showed that it is applicable for one-way ANOVA. After seeing Levene test result is proper, then one-way ANOVA is applied, however, it is found that there is no difference according to firm size for supply chain orientation. Moreover, to see whether there is a difference between ownership structure and supply chain performance, again Levene test is applied and results showed that it is applicable for one-way ANOVA. After seeing Levene test result is proper, then one-way ANOVA is applied, however, it is found that there is no difference according to ownership structure for supply chain orientation.

In this study, suppliers' orientation and suppliers' brand equity factors affect supply chain orientation hypotheses tested with regression analysis. Before starting to form regression model, assumptions are tested. For this purpose, the assumption of normality for dependent and independent variables checked and it is observed that normal distribution has not degenerated. After that, by controlling homoscedasticity matrix, it is seen that the assumption of constant variance is proper.

After verifying assumptions, recommended hypotheses tested with regression analysis and results are shown in Table 7, Table 8, Table 9, Table 10 and Table 11. According to regression analysis results, H1.1.a, H1.1.c, H1.2.a, H1.2.c, H2.1, H3.3, H4.1, H5.2.a, H5.2.b, H5.3.a and H5.3.b found validated respectively. Suppliers' corporate norms affects suppliers' brand image $\left(R^{2}=0.528, p=0.001<0.05\right)$, suppliers' brand trust $\left(R^{2}=0.439, p=0.008<0.05\right)$ and suppliers' brand equity positively $\left(R^{2}=0.343, p=0.044<0.05\right)$; while suppliers' credibility \& commitment affects suppliers' brand image $\left(R^{2}=\right.$ $0.439, p=0.008<0.05)$ and suppliers' brand trust positively $\left(R^{2}=0.586, p=0.000<0.05\right)$. According to results, suppliers' brand trust affects suppliers' equity positively $\left(R^{2}=0.349, p=0.040<0.05\right)$. Moreover, it is seen that suppliers' brand equity affects supply chains' cost \& service-based performance positively $\left(R^{2}=0.526, p=0.001<0.05\right)$. Thus, it is seen that suppliers' brand image affects supply chain's cost \& service-based performance $\left(R^{2}=0.396, p=0.018<0.05\right)$ and supply chains' time \& operation-based performance positively $\left(R^{2}=0.059, p=0.000<0.05\right)$. Lastly, it is found that suppliers' brand trust affects supply chain's cost \& service-based performance $\left(R^{2}=0.512, p=0.002<0.05\right)$ and supply chains' time \& operation-based performance positively $\left(R^{2}=0.607, p=0.000<0.05\right)$.

Table 7: Results of Hypothesis Tests (H1)

\begin{tabular}{|c|c|c|c|c|}
\hline Hypothesis & & $\begin{array}{l}\text { Pearson } \\
\text { Correlation }\end{array}$ & $\begin{array}{l}\text { Sig. (2- } \\
\text { tailed) }\end{array}$ & Result \\
\hline H1. & $\begin{array}{l}\text { Suppliers' supply chain orientation affects suppliers' brand factors } \\
\text { positively. }\end{array}$ & & & \\
\hline H.1.1. & Suppliers' corporate norms affect brand factors positively. & & & \\
\hline H1.1a & Suppliers' corporate norms affect brand image positively. & $.528 * *$ & .001 & Accepted \\
\hline H1.1.b & Suppliers' corporate norms affect brand awareness positively. & .188 & .280 & Rejected \\
\hline H1.1.c & Suppliers' corporate norms affect brand trust positively. & $.439 * *$ & .008 & Accepted \\
\hline H1.1.d & Suppliers' corporate norms affect brand communication positively. & .064 & .716 & Rejected \\
\hline H1.2. & Suppliers' credibility \& commitment affects brand factors positively. & & & \\
\hline H1.2.a & Suppliers' credibility \& commitment affects brand image positively. & $.439 * *$ & .008 & Accepted \\
\hline H1.2.b & Suppliers' credibility \& commitment affects brand awareness positively. & .249 & .150 & Rejected \\
\hline H1.2.C & Suppliers' credibility \& commitment affects brand trust positively. & $.586 * *$ & .000 & Accepted \\
\hline H1.2.d & Suppliers' credibility \& commitment affects brand communication positively. & -.077 & .660 & Rejected \\
\hline
\end{tabular}

${ }^{*}$ Correlation is significant at the 0.05 level (2-tailed)

** Correlation is significant at the 0.01 level (2-tailed) 
Table 8: Results of Hypothesis Tests (H2)

\begin{tabular}{|c|c|c|c|c|}
\hline Hypothesis & & $\begin{array}{l}\text { Pearson } \\
\text { Correlation }\end{array}$ & $\begin{array}{l}\text { Sig. (2- } \\
\text { tailed) }\end{array}$ & Result \\
\hline H2. & $\begin{array}{l}\text { Suppliers' supply chain orientation affects suppliers' brand equity } \\
\text { positively. }\end{array}$ & & & \\
\hline H2.1 & Suppliers' corporate norms affect brand equity positively. & $.343^{*}$ & .044 & Accepted \\
\hline H2.2 & Suppliers' credibility \& commitment affects brand equity positively. & .305 & .075 & Rejected \\
\hline
\end{tabular}

${ }^{*}$ Correlation is significant at the 0.05 level (2-tailed)

** Correlation is significant at the 0.01 level (2-tailed)

Table 9: Results of Hypothesis Tests (H3)

\begin{tabular}{|c|c|c|c|c|}
\hline Hypothesis & & $\begin{array}{c}\text { Pearson } \\
\text { Correlation }\end{array}$ & $\begin{array}{l}\text { Sig. (2- } \\
\text { tailed) }\end{array}$ & Result \\
\hline H3 & Suppliers' brand factors affect suppliers' brand equity positively. & & & \\
\hline H3.1 & Suppliers' brand awareness affects suppliers' brand equity positively. & 0.72 & .680 & Rejected \\
\hline H3.2 & Suppliers' brand image affects suppliers' brand equity positively. & .309 & .071 & Rejected \\
\hline H3.3 & Suppliers' brand trust affects suppliers' equity positively. & $.349 *$ & .040 & Accepted \\
\hline H3.4 & Suppliers' brand communication affects suppliers' brand equity positively. & -.068 & ,698 & Rejected \\
\hline
\end{tabular}

*Correlation is significant at the 0.05 level (2-tailed)

** Correlation is significant at the 0.01 level (2-tailed)

Table 10: Results of Hypothesis Tests (H4)

\begin{tabular}{|c|c|c|c|c|}
\hline Hypothesis & & $\begin{array}{l}\text { Pearson } \\
\text { Correlation }\end{array}$ & $\begin{array}{l}\text { Sig. (2- } \\
\text { tailed) }\end{array}$ & Result \\
\hline H4 & Suppliers' brand equity affects supply chain performance positively. & & & \\
\hline H4.1 & $\begin{array}{l}\text { Suppliers' brand equity affects supply chain's cost \& service-based } \\
\text { performance. }\end{array}$ & $.526 * *$ & .001 & Acceptec \\
\hline H4.2 & $\begin{array}{l}\text { Suppliers' brand equity affects supply chain's time \& operation-based } \\
\text { performance. }\end{array}$ & .260 & .131 & Rejected \\
\hline
\end{tabular}

${ }^{*}$ Correlation is significant at the 0.05 level (2-tailed)

** Correlation is significant at the 0.01 level (2-tailed)

Table 11: Results of Hypothesis Tests (H5)

\begin{tabular}{|c|c|c|c|c|}
\hline Hypothesis & & $\begin{array}{l}\text { Pearson } \\
\text { Correlation }\end{array}$ & $\begin{array}{l}\text { Sig. (2- } \\
\text { tailed) }\end{array}$ & Result \\
\hline H5 & Suppliers' brand factors affect supply chain performance positively. & & & \\
\hline H5.1 & Suppliers' brand awareness affects supply chain performance positively. & & & \\
\hline H5.1.a & $\begin{array}{l}\text { Suppliers' brand awareness affects supply chain's cost \& service-based } \\
\text { performance. }\end{array}$ & -.024 & .889 & Rejected \\
\hline H5.1.b & $\begin{array}{l}\text { Suppliers' brand awareness affects supply chain's time \& operation-based } \\
\text { performance. }\end{array}$ & .270 & .117 & Rejected \\
\hline H5.2 & Suppliers' brand image affects supply chain performance positively. & & & \\
\hline H5.2.a & $\begin{array}{l}\text { Suppliers' brand image affects supply chain's cost \& service-based } \\
\text { performance. }\end{array}$ & $.396 *$ & .018 & Accepted \\
\hline H5.2.b & $\begin{array}{l}\text { Suppliers' brand image affects supply chain's time \& operation-based } \\
\text { performance. }\end{array}$ & $.059 * *$ & .000 & Accepted \\
\hline H5.3 & Suppliers' brand trust affects supply chain performance positively. & & & \\
\hline H5.3.a & Suppliers' brand trust affects supply chain's cost \& service-based performance. & $.512^{* *}$ & .002 & Accepted \\
\hline H5.3.b & $\begin{array}{l}\text { Suppliers' brand trust affects supply chain's time \& operation-based } \\
\text { performance. }\end{array}$ & $.607 * *$ & .000 & Accepted \\
\hline H5.4 & Suppliers' brand communication affects supply chain performance positively. & & & \\
\hline H5.4.a & $\begin{array}{l}\text { Suppliers' brand communication affects supply chain's cost \& service-based } \\
\text { performance. }\end{array}$ & -.261 & .130 & Rejected \\
\hline H5.4.b & $\begin{array}{l}\text { Suppliers' brand communication affects supply chain's time \& operation-based } \\
\text { performance. }\end{array}$ & -.400 & .400 & Rejected \\
\hline
\end{tabular}

${ }^{*}$ Correlation is significant at the 0.05 level (2-tailed)

** Correlation is significant at the 0.01 level (2-tailed) 


\section{CONCLUSION}

This research examines how suppliers' supply chain orientation and brand equity affects overall supply chain performance in the context of manufacturing companies; while contributing our understanding of brand in B2B service settings. For this purpose, a scale has been developed considering supply chain orientation, brand equity, and supply chain performance. The online survey sent to Aegean Exporters' Association, ESBAS Aegean Free Zone and Manisa Organized Industrial Zone, and with 35 responses analysis has been made with using SPSS21.0. The findings provide evidence that when a supplier has corporate norms and credibility and commitment values, it positively affects supplier's brand image and brand trust. Moreover, it is seen that supplier's corporate norms affect supplier's overall brand equity as well. Second, it is validated that suppliers' brand trust has a positive impact on suppliers' brand equity. Third, it is seen that suppliers' brand equity impacts whole supply chain's cost \& service-based performance. Finally, it is found that both suppliers' brand image and brand trust impact whole supply chain's both cost- \& service-based and time- \& operation-based performance.

\subsection{Managerial Implications}

This study provides a number of important implications for management. First, the study results reveal the importance of supplier's supply chain orientation within a supply chain if partners want to develop a high-performing supply chain. In addition, the study was able to show the importance of supplier's brand trust in band equity. Managers generally think that the only relationship between is the brand and customer. However, this study shows that brand trust is also affected firm's brand equity.

The study results further show that supplier's brand image and brand trust have distinctive roles in inducing better supply chain performance; meaning that if supply chain managers consider their supplier's brand image and brand trust during supplier selection process, supply chain as a whole can achieve higher supply chain performance.

\subsection{Limitations and Suggestions for Future Research}

There are some limitations of the study with regards to the time limit and the low return rate. Although great effort was spent to increase the number of questionnaires answered by the participants, only 35 managers answered the questionnaire. This can be considered as the main limitation of the study since a low response rate limits the generalizability of the results of the survey. When related studies concentrated on manufacturing companies and specifically supply chain managers are considered (Davis et al., 2008; Davis et al., 2009; Kim and Cavusgil, 2009), it was observed that there is a similar pattern in such studies.

This study employed brand awareness, brand image and brand trust for brand equity dimensions. Future studies may be conducted for exploring for different brand equity characteristics. Investigating the antecedents of brand awareness, brand image, and brand trust can also be suggested for providing an overview especially for logistics managers who want to improve their firms' brand. In the study, one participant is used, however; collecting data from multiple participants within a company can be another future research idea. There are numerous exogenous or moderating variables that affect brand equity. In a future study, those variables can also be examined. By using different conceptualizations and dimensions of SCO, a different perspective can also be used. Thus, conducting a study with these dimensions would be informative to see if additional dimensions improve the exploratory power of the model. Also, the same study can be applied again to the different sample with high return rate. Moreover, this scale can be used for the manufacturing firm and its suppliers simultaneously to see how partners in the same supply chain see each other and how firms' brand positioned partners' mind.

\section{REFERENCES}

Aaker, D.A., 1991. Managing Brand Equity: Capitalizing on the Value of a Brand Name. New York, NY: The Free Press.

Aaker, D.A., 1996. Measuring brand equity across products and markets, California Management Review, 38(3), 102-120.

Aaker, D., 2003. The power of the branded differentiator, Sloan Management Review, 83-87.

Anderson, J.C., \& Narus, J.A., 1990. A model of distributor firm and manufacturer firm working partnership, Journal of Marketing, 54(1), 4258. DOI: https://doi.org/10.2307/1252172

Ashley, C., and Leonard, H.A., 2009. Betrayed by the buzz? Convert content and consumer-brand relationships, Journal of Public Policy and Marketing, 28(2), 212-220. https://doi.org/10.1509/jppm.28.2.212

Bendixen, M., Bukasa, K.A., and Abratt, R., 2004. Brand equity in the business-to-business market, Industrial Marketing Management, 33(5), 371-380. https://doi.org/10.1016/j.indmarman.2003.10.001 
Berry, L.L. 1995. Relationship marketing of services: growing interest, emerging perspectives, Journal of Academy of Marketing Science, 23(4), 236-245.

Bhatnagar, R., and Sohal, A.S., 2005. Supply chain competitiveness: measuring the impact of location factors, uncertainty and manufacturing practices, Technovation, 25, 443-456. https://doi.org/10.1016/j.technovation.2003.09.012

Brewer, P.C., and Speh, T.W., 2000. Using the balanced scorecard to measure supply chain performance, Journal of Business Logistics, 21(1), 75- 93.

Bucklin, L.P., and Sengupta, S., 1993. Organizing successful co-marketing alliances, Journal of Marketing, 57,32-46. DOI: https://doi.org/10.2307/1252025

Buil, I., de Charnatony, L., and Martinez, E., 2008. A cross-national validation of the consumer-based bran equity scale, Journal of Product \& Brand Management, 17(6), 384-392. https://doi.org/10.1108/10610420810904121

Cannon, J.P., and Perreault, Jr., W.D., 1999. Buyer-seller relationships in ibusiness markets, Journal of Marketing Research, 36, 439-460. https://doi.org/10.2307/3151999

Carpenter, G., and Nakamoto, K., 1989. Consumer preference formation and pioneering advantage, Journal of Marketing Research, 26(3), 285-298. https://doi.org/10.2307/3172901

Carroll, B.A., and Ahuvia, A.C., 2006. Some antecedents and outcomes of brand love, Market Letter, 17, 79-89.

Celi, L., and Eagle, J., 2008. Ten Megatrends in B2B Marketing, The Economist-Economist Intelligence Unit.

Chaudhuri, A., and Holbrook, B.M., 2001. The chain of effects from brand trust and brand affects to brand performance: the role of brand loyalty, Journal of Marketing, 65, 81-93.

Christopher, M., 1992. Logistics and Supply Chain Management, Pitmann Publishing, London.

Cho, E., 2011. Development of a brand image scale and the impact of lovemarks on brand equity, Published Dissertation, lowa State University, USA.

Cohen, M.A., and Lee, H.L., 1990. Out of touch with customer needs? Spare parts and after sales service, Sloan Management Review, 31(2), 55-66.

Davis, S.M., 2000. Brand Asset Management, Jossey-Bass, San Francisco, CA.

Davis, T., 2003. Effective supply chain management, Sloan Management Review, 34(4), 35-46.

Davis, D.F., Golicic, S.L., and Marquardt, A.J., 2008. Branding a B2B service: does a brand differentiate a logistics service provider?, Industrial Marketing Management, 37, 218-227.

Davis, D.F., Golicic, S.L., and Marquardt, A., 2009. Measuring brand equity for logistics services, International Journal of Logistics Management, 20(2), 201-212. https://doi.org/10.1108/09574090910981297

Deighton, J., 1992. The consumption of performance, Journal of Consumer Research, 19, 362-372. http://www.jstor.org/stable/2489394

Delgado-Ballester, E., 2011. Development and Validation of a Brand Trust Scale.

Dobni, D., and Zinkhan, G.M., 1990. In search of brand image: a foundation analysis, Advances for Consumer Research, eds. Goldberg, M.E., Gom, G., Pollay R.W., Vol.17, pp.110-118.

Doney, P. M., and Cannon, J.P., 1997. An Examination of the Nature of Trust in Buyer-Seller Relationships, Journal of Marketing, 65, 35-51. https://doi.org/10.2307/1251829

Dwyer, R.F., Schurr, P.H., and Oh, S., 1987. Developing buyer-seller relationships, Journal of Marketing, 54, 11-27.: https://doi.org/10.2307/1251126

Erdem, T., Swait, J., and Valenzuela, A., 2006. Brands as signals: a cross- country validation study, Journal of Marketing, 70(1), 34-49. https://doi.org/10.1509/jmkg.2006.70.1.34

Faircloth, J.B., 2005. Factors influencing nonprofit resource provider support decision: applying the brand equity concept to nonprofit, Journal of Marketing Practice and Theory, 9(3), 61-75. https://doi.org/10.1080/10696679.2005.11658546

Farquhar, P.H., 1989. Managing brand equity, Marketing Research, 1(3), 24-33.

Field, A., 2005. Discovering Statistics Using SPSS ( $2^{\text {nd }}$ Edition). London: Sage Publication.

Ganesan, S., 1994. Determinants of long-term orientation in buyer-seller relationships, Journal of Marketing, 58, 1-19. https://doi.org/10.2307/1252265

Glynn, M.S., 2015. Chapter 10 Analyzing the B2B Brand Value Chain, In Business-to-Business Marketing Management: Strategies, Cases and Solutions. Online Publishing. 
Gordon, G.L., Calantone, R.J., and di Benedetto, C.A., 1993. Brand equity in the business-to-business sector: an exploratory study, Journal of Product and Brand Management, 2(3), 4-16. https://doi.org/10.1108/10610429310046689

Gunasekaran, A., Paterl, C., and Tirtiroglu, E., 2001. Performance measures and metrics in a supply chain environment, International Journal of Operations and Product Management, 21(1/2), 71-87. https://doi.org/10.1108/01443570110358468

Gunasekaran, A., Patel, C., and McGaughey, R.E., 2004. A framework for supply chain performance measurement, International Journal of Production Economics, 87, 333-347. https://doi.org/10.1016/j.ijpe.2003.08.003

Gawankar, S., Kamble, S. and Raut, R., 2016. Development, measurement and validation of supply chain performance measurement (scpm) scale in Indian retail sector, Benchmarking: An International Journal, 23(1), 25-60. https://doi.org/10.1108/BIJ-06-2013-0068

Han, S. L., and Sung, H.S., 2008. Industrial brand value and relationship performance in business markets- a general structural equation model, Industrial Marketing Management, 37, 807-818. https://doi.org/10.1016/j.indmarman.2008.03.003

Hoek, R.I., 1998. Measuring the unmeasurable - measuring and improving performance in the supply chain, Supply Chain Management: An International Journal, 3(4), 187-192. https://doi.org/10.1108/13598549810244232

Homburg, C., Klarmann, M., and Schmitt, J., 2010. Brand awareness in business markets: when is it related to firm performance, International Journal of Research in Marketing, 27, 201-212. https://doi.org/10.1016/j.ijresmar.2010.03.004

Hoyer, W.D., and Brown, S.P., 1990. Effects of brand awareness on choice for a common, repeat purchase product, Journal of Consumer Research, 17, 141 - 148. http://www.jstor.org/stable/2626806

Hutton, J., 1997. A study of brand equity in an organizational context, Journal of Product and Brand Management, 6(6), 428-439. https://doi.org/10.1108/10610429710190478

Jaworski, B.J., and Kohli, A.K., 1993. Market orientation: antecedents and consequences, Journal of Marketing, 57(3), 53-70. https://doi.org/10.2307/1251854

Keller, K.L., 1993. Conceptualizing, measuring and managing customer-based brand equity, Journal of Marketing, 57 , 1-22. https://doi.org/10.2307/1252054

Keller, K.L., 2001. Building customer-based brand equity: a blueprint for creating strong brands, Marketing Science Institute, Working Paper, 01- 107

Keller, K.L., and Lehmann, D.R. 2003. How do brands create value?, Marketing Management, 12(3), 26-31.

Keller, K, L., 2008. Strategic Brand Management: Building, Measuring and Managing Brand Equity, $3^{\text {rd }}$ Edition, New Jersey, New York.

Kim, H, Kim, W.G., and An. J.A., 2003. The effects of consumer-based brand equity on firm's financial performance, Journal of Consumer Marketing, 20(4), 335-351. pp.335-351, https://doi.org/10.1108/07363760310483694

Kim, D., and Cavusgil, E., 2009. The impact of supply chain integration on brand equity, Journal of Business and Industrial Marketing, 24(7), 496-505. https://doi.org/10.1108/08858620910986730

Kim, E.Y., Knight, D.K., and Pelton, L.E., 2009. Modeling brand equity of a US apparel brand as perceived by generation y consumers in the emerging Korean market, Clothing and Textiles Research Journal, 27(4), 247-258

Kim, J.H., and Hyun, Y.J., 2011. A model to investigate the influence of marketing- mix efforts and corporate image on brand equity in the it software sector, Industrial Marketing Management, 40, 424-438. https://doi.org/10.1016/j.indmarman.2010.06.024

Kimpakorn, N., and Tocquer, G., 2010. Service brand equity and employee brand commitment, Journal of Service Marketing, 25(5), 378388. https://doi.org/10.1108/08876041011060486

Kotler, P., 1997. Marketing Management, $7^{\text {th }}$ Edition, Englewood Cliffs, NJ: Prentice-Hall.

Kotler, P., and Proertsch, W., 2007. Being known or being one of many: the need for brand management for business-to-business companies, Journal of Business and Industrial Marketing, 22(6), 357-362.

Kumar, N., Scheer, L.K., and Steenkamp, J.B., 1995. The effects of supplier fairness on vulnerable resellers, Journal of Marketing Research, 32, 54-65. https://doi.org/10.2307/3152110

Lambert, D.M., and Sharman, A., 1990. A customer-based competitive analysis for logistics decisions, International Journal of Physical Distribution and Logistics Management, 20(1), 17-24. https://doi.org/10.1108/EUM0000000000350

Lambert, D.M., Stock, J.R., and Ellram, L.M. 1998. Fundamentals of Logistics Management, Irwin/McGraw-Hill

Laroche, M., Kim, C., and Zhou, L., 1996. Brand familiarity and confidence as determinants of purchase intention: an empirical test in a multiple brand context, Journal of Business Research, 37(2), 115-120. https://doi.org/10.1016/0148-2963(96)00056-2

Lee, H.L., and Billington, C., 1992. Managing supply chain inventory: pitfalls and opportunities, Sloan Management Review, 33(3), 65-73.

Levy, D.L., 1995. International sourcing and supply chain stability, Journal of International Business Studies, 26(2), 343-360. 
Loforte, A.J., 1993. The implications of multicultural relationship in a transnational supply chain, In Annual Conference Proceedings, National Association of Purchasing Management, 69-77.

Lorge, S.R., 1998. Better off branded, Sales and Marketing Management, 150(3), 39-42.

Low, G.S., and Lam, C.W., 2000. The measurement and dimensionality of brand associations, Journal of Product and Brand Management, 9(6), 350-368. https://doi.org/10.1108/10610420010356966

Lyons, A.C., Mondragon, A.E.C., Piller, F., and Poler, R., 2012. Glass pipelines: the role of information systems in supporting customer-driven supply chains, Decision Engineering, London, 45-70. https://doi.org/10.1007/978-1-84628-876-0_3

MacDonald, E.K., and Sharp B.M., 2000. Brand awareness effects on consumer decision making for a common, repeat purchase product: making for a common, repeat purchase product: a replication, Journal of Business Research, 48, 5-15. https://doi.org/10.1016/S01482963(98)00070-8

Mentzer, J.T. (Ed.), 2001. Supply Chain Management, Sage, Thousand Oaks, CA.

Mentzer, J.T., DeWitt, W., Keebler, J.S., Min, S., Nix, N.W., Smith, C.D., and Zacharia, Z.G., 2001. Defining supply chain management, Journal of Business Logistics, 22,1-25. https://doi.org/10.1002/j.2158-1592.2001.tb00001.x

Milgrom, P., and Roberts, J., 1986. Price and advertising signals of product quality, Journal of Political Economy, 94(4), $796-821$. http://www.jstor.org/stable/1833203

Min, S., Mentzer, J.T., and Ladd, R.T., 2007. A market orientation in supply chain management, Journal of the Academy of Marketing Science, 35, 507-522.

Motameni, R., and Shahrokhi, M., 1998. Brand equity valuation: a global perspective, Journal of Product \& Brand Management, 7(4), 275290. https://doi.org/10.1108/10610429810229799

Mudambi, S.M., Doyle, P., and Wong, V., 1997. An exploration of branding in industrial markets, Industrial Marketing Management, 26(5), 433-446. https://doi.org/10.1016/S0019-8501(96)00151-4

Mudambi, S.M., 2002. Branding importance in business-to-business markets: three buyer clusters, Industrial Marketing Management, 31(6), 321-331. https://doi.org/10.1016/S0019-8501(02)00184-0

Munoz, T., and Kumar, S., 2004. Brand metrics: gauging and linking brands with business performance, Journal of Brand Management, 11(5), 381-387.

Padgett, D. and Allen D., 1997. Communicating experiences: a narrative approach to creating service brand image, Journal of Advertising, 26(4), 49-62. http://www.jstor.org/stable/4189050

Porter, L.W., Steers, R.M., Mowday, R.T., and Boulian, P.V., 1974. Organizational commitment, job satisfaction and turnover among psychiatric technicians, Journal of Applied Psychology, 59,603-609. http://dx.doi.org/10.1037/h0037335

Pouromid, B., and Iranzadeh, S., 2012. The evaluation of the factors effects on the brand equity of pars Khazar household appliances based on the vision of female consumer, Middle-East Journal of Scientific Research, 12(8), 1050-1055. https://doi.org/10.5829/idosi.mejsr.2012.12.8.1796

Ravald, A. and Grönross, C., 1996. The value concept and relationship marketing, European Journal of Marketing, 30(2), 19-30. https://doi.org/10.1108/03090569610106626

Rempel, J.K., Holmes, J.G., and Zanna, M.P., 1985. Trust in close relationships, Journal of Personality and Social Psychology, 49(1), 95-112. https://doi.org/10.1037//0022-3514.49.1.95

Roberts, J., and Merrilees, B., 2007. Multiple roles of brands in business-to-business services, Journal of Business and Industrial Marketing, 22(6), 410-417. https://doi.org/10.1108/08858620710780172

Roper, S., Davies, G., and Murphy, J., 2002. Linking atmosphere and reputation in order to measure business-to-business relationships, Journal of Customer Behavior, 1, 215-235. https://doi.org/10.1362/14753920260595228

Roy, D., and Banerjee, S., 2007. CARE-ing strategy for integration of brand identity with brand image, International Journal of Commerce and Management, 17( 1/2), 7-21. https://doi.org/10.1108/10569210710776512

Sahay, B.S., 2003. Understanding trust in supply chain relationships, Industrial Management \& Data Systems, 103(8), 553-563. https://doi.org/10.1108/02635570310497602

Shaw, J., Giglierano, J., and Kallis, J., 1989. Marketing complex technical products: the importance of intangible attributes, Industrial Marketing Management, 18, 45-53. https://doi.org/10.1016/0019-8501(89)90020-5

Sheth, J.N., and Parvatiyar, A., 2000. Handbook of Relationship Marketing, Sage Publications, London.

Siguaw, J.A., Simpson, P.M., and Baker, T.L, 1998. Effects of supplier market orientation on distributor market orientation and the channel relationship: the distributor perspective, Journal of Marketing, 62, 99-111. DOI: 10.2307/1251746 
Simon, C.J., and Sullivan, M.W., 1993. The measurement and determinants of brand equity: a financial approach, Marketing Science, 12(1), 28-52. https://doi.org/10.1287/mksc.12.1.28

Sinclair, S.A., and Seward, K.E., 1988. Effectiveness of branding a commodity product, Industrial Marketing Management, 17, 23-33. https://doi.org/10.1016/0019-8501(88)90023-5

Stewart, G., 1995. Supply chain performance benchmarking study reveals keys to supply chain excellence, Logistics Information Management, 8(2), 38-44. https://doi.org/10.1108/09576059510085000

Taylor, S.A., Hunter, G.L., and Lindberg, D.L., 2007. Understanding (customer-based) brand equity in financial services, Journal of Services Marketing, 21(4), 241- 252. https://doi.org/10.1108/08876040710758540

Tinney, J.M., 2012. The effects of supply chain orientation, supply chain management and collaboration on perceived firm performance, Graduate Research Project, Air Force Institute of Technology, Ohio.

Tucker, T.R., 2011. Supply chain orientation: refining a nascent construct, PhD. Dissertation, Waterloo, Ontario, Canada

Webster, F.E., Jr., and Keller, K.L., 2004. A roadmap for branding in industrial markets, Journal of Brand Management, 11(5), 388-402.

Yoo, B., Donthu, N. and Lee, S., 2000. An examination of selected marketing mix elements and brand equity, Journal of the Academy of Marketing Science, 28(2), 195-211.

Yoo, B., and Donthu, N., 2001. Developing and validating a multi-dimensional consumer-based brand equity scale, Journal of Business Research, 52(1), 1-14. https://doi.org/10.1016/S0148-2963(99)00098-3

Yoo, B., and Donthu, N., 2002. Testing cross-cultural invariance of the brand equity creation process, Journal of Product \& Brand Management, 11(6), 380-398. https://doi.org/10.1108/10610420210445505

Zaichkowsky, J.L., Parlee, M., and Hill, J., 2010. Managing industrial brand equity: developing tangible benefits for intangible assets, Industrial Marketing Management, 39, 776-783. https://doi.org/10.1016/j.indmarman.2010.02.017 